\title{
An Empirical Model of Indian Foreign Investment and Stock Market Volatility: Evidence From ARDL Bounds Testing Analysis
}

\author{
Amar Singh ${ }^{1} \&$ Arvind Mohan ${ }^{1}$ \\ ${ }^{1}$ Department of Management Studies, Graphic Era Deemed to be University, Uttarakhand, India \\ Correspondence: Amar Singh, Research Scholar, Department of Management Studies, Graphic Era Deemed to be \\ University, Clement Town, Bell Road, Dehradun, Uttarakhand, 248001, India. Tel: 91-9837-777-273.
}

Received: July 2, 2019

doi:10.5430/ijfr.v11n2p154
Accepted: December 13, 2019

Online Published: March 17, 2020

URL: https://doi.org/10.5430/ijfr.v11n2p154

\begin{abstract}
Foreign investment is a major factor to determine volatility in the stock market. To discover the influence on Stock Market volatility of foreign investment we have considered FE, FD, and FDI as proxy variables of foreign investment and Indian stock market volatility is represented by Indian vix. The period for this study is 2009 to 2017 (monthly data). To address this issue of volatility in the long/short-run we have applied the ARDL. The preference given to the ARDL model over Johansen co-integration is to the difference in the order of integration among the variables. ARDL model allows us to combine the I(0) and I(1) series whereas I(1) required in the case of Johansen approach. Results of unit root confirm the $\mathrm{I}(0) / \mathrm{I}(1)$ order of integration, which allows us to apply the ADRL bound test. F-statistics is higher than the upper bound critical value at $10 \%, 5 \%$ and providing the evidence of co-integration among variables at a 5\% level of significance. Hence, there is a long-run relationship amid the variables. Long-run form results show the negative sign of the coefficient and it is significant. The ECM value is (-0.9671) and it confirms that nearly $96.71 \%$ of the inaccuracy rose in each period and automatically corrected in specified time period.
\end{abstract}

Keywords: ARDL, foreign equity, foreign debt, foreign direct investment, Indian volatility index

JEL: F2, G1

\section{Introduction}

Numerous studies were drawn to study and analyze the influence of macro-economic elements on Stock-Market index and the majority of them were generally attended towards industrialized economies along with the impact of these macro-economic elements on the Stock -Market index in countries where the development is low.

The Stock market considers an effective source in mobilizing money as well as assigning of saved resources amid competitors which interprets decisive for development and effectiveness economy (Unkoro \& Uko, 2013). (Siliverstovs \& Duong, 2006) investigated the interrelationships among the Stock market, GDP and rate of interest in five (5) European nations, namely, Germany, France, Italy, Netherlands, and the UK. They concluded that there exists a favorable correlation among stock prices and GDP in aforesaid nations. (Lensink \& Morrisey, 2006) stated that the instability of FDI has an unfavorable influence on expansion and at the same time, the results are not completely vigorous. They estimated the standard model by using cross-section, panel data along with instrumental variable techniques.

(Sehgal \& Tripathi, 2009) calculated that if Foreign Institutional Investors (FIIs) assume favorable response and flocked strategies in the Indian environment, FIIs reveal about return chasing patterns while using monthly data. Though, it pretends to be working on the affirmative opinion if used daily files. They stay for the information generated from the market to resolve and not reacted immediately. Furthermore, FIIs depicts much aware about the company's essentials at personal stock level. The behavior of market series may keep on changes for individual stocks. Their results have tough inferences for domestic FIs, portfolio managers, wealth managers and other investors along with regulations of market who want to have a healthier perspective of FII's pattern as later are the leading investors in the Indian equity market.

(Ikoku, 2010) studied the connection between stock market prices, real Gross Domestic Product and the indicator of industrial production in Nigeria by using periodical data from first quarter of 1984 to fourth quarter of 2008. Bidirectional relationship occurs among stock prices and GDP while no connection arises among stock prices and 
industrial production/ among GDP and industrial production which was tested by Granger causality tests. Stock market prices and GDP were initiated to be cointegrated through the assessment of Vector Error correction models.

More than 70 years ago, in 1938, Mitchell \& Burns has incorporated the Dow Jones composite indicator of Stock prices for the U.S. economy in the index of leading indicators. The majority of studies in African Stock markets primary concentrated on the function of stock market growth which was considered via proportion of market capitalization to GDP in economic development. (Osinubi, 2002; Adebiyi, 2005 \& Narudeen, 2009) investigated the affirmative relationship among stock market development and economic growth in Nigeria. With the emergence of more economic actions worldwide, international trade and investment have contributed effective role on a large scale. David Ricardo has proposed comparative advantage theory and afterward pursued by Hecksher and Ohlin on factor abundant theory concluded the influence of international trade and investment. Any nation must manufacture and sell overseas products that are reasonably rich as compared to trade in products that are reasonably less in its country (Pugel, 2015).

In the terminology of stock returns, Volatility means divergence in the prices of stock changes all over a point (Zafar et al., 2008). The movement of stock market depends on the strength of financial scheme, macro-economic firmness and also affected external markets (Aliyu, 2012). (Officer, 1973) who is an established investigator connected volatility of stock price with economic indicators and found that in the 1930s there was a high amount of volatility during the big depression? According to (Wei-cheng et al., 2011), normally, both developed and underdeveloped economies are volatile stock markets. People who wanted to invest always recognize the temperament of instability. Numerous studies are conducted which show asymmetric connection among stock returns and stock volatility. Further, good news and bad news have a distinct influence on volatility (Campbell \& Hentschel, 1992). (Karolyi, 2001) examined that if there is decline in stock prices then stock market shows high volatile and vice versa. Previously, (Bollersley et al., 1994) found that negative shocks lead to high volatility in comparison to positive shocks of similar magnitude.

\section{Literature Review}

As per the study conducted by (Schwart,1989), the Stock market volatility may lean to be long-lasting and persistent, it refers that time duration of high along with low volatility may last maximum for months. The researcher found that the duration of high instability probably arises during fall in stock prices also at the time of depression.

The favourable and strong associations among stock market liquidity and fast growth rates, enhancement in capacity, and fund accumulation authenticate by (Levine, 1991 \& Bencivenga et al., 1995) in their theoretical predictions.

(Levine \& Zervos, 1998) in their research practically observes that whether the process of stock market size, liquidity, volatility and incorporation through global capital markets are vigorously related with present and prospective rates of GDP, capital accumulation, productivity improvements as well as saving rates with the help of statistics on 47 countries from 1976 to 1993. Stock market liquidity considered as a strong forecaster of real per capita GDP, physical capital growth along with growth of productivity followed by initial income, political stability, initial investment in edification, fiscal policy, trade openness, stability for macroeconomic as well as the futuristic stock prices.

(Choe, Kho \& Stulz, 1999) examined that though the foreign investors employ favourable opinion on trading and live stock rearing before the Korean Financial Crisis in 1997, but foreign investors in reverse trail the unfavourable response on trading strategies at the time of financial crisis.

(Huang \& Yang, 2000) examined whether the market liberalization of ten developing countries leads towards high volatile local stock markets or not and they concludes that the price of stock becomes highly unstable in South Korea, Turkey and Mexico while less unstable in Philippines, Argentina, Malaysia and Chile. There exists no considerable prototype for other markets which includes Taiwan and Thailand as well as Brazil.

(Errunza, 2001) have analyzed that Foreign institutional investors flows does not found any favourable influence on accelerating volatility in stock markets of prospective market economies.

(Kim \& Singal, 2000; Miles, 2002) explored the influence of developing stock markets openness to FI (foreign investors) on stock prices fluctuations. Their conclusions reveal that the grant of FI (Foreign Investor) to trade stocks in future markets does not add to the stock market volatility.

(Fitz, 2003) has examined that generally, the stock market in emerging economies be deficient in the depth and breadth, therefore, involvement of foreign institutional investors can make substantial dependability and volatility in stock markets. Stock market Volatility acts an essential element in the economic standard deviation of the natural log 
on daily returns on the indices. Instability is innermost part to risk management in an economy. It is very complex to construct a common analysis regarding the features and degree of Stock market volatility along with its causal correlation with Foreign institutional investor inflows.

(Bae, Chan \& Ng, 2004) certified an affirmative inter relationship among foreign investment limitations and regional firm stock return volatility. They argued that as soon as a regional firm is extremely reachable to FI (foreign investors), its trading in stock determines an international investment flows, and consequently their returns in stock seems at high risk to global market risk. (Pavabutr \& Yan, 2007) observed the causes of expected and unexpected foreign flows mutually on daily basis as well as on weekly basis of stock return volatility in Thailand stock market from the period 1995-2002. The unexpected foreign flows were found to have a favourable influence on stock return volatility while analysed on both daily and weekly basis. On the other hand, the impact of the expected foreign flows is found insignificant.

(Law \& Ngah, 2008) also found opinionated proof for the decline in Malaysian Stock market Volatility after liberalization. The researchers inspect the consequence from 1985-2006 of equity market liberalization on volatility in Malaysian stock market with the help of EGARCH model.

(Behera, 2010) considered the consequences of Foreign Institutional Investors' (FIIs) equity return on investment as well as instability with the help of (OLS) GARCH. The research resulted that FIIs' investment have a favourable influence on both liquidity as well as returns and GARCH model proposed that FIIs' investments will boost the instability in Indian stock market. The FIIs has a vital role in stabilising as market makers and reserve their returns, it means that they purchase financial securities once their prices are low and sell when its prices are high (Gupta \& Gordon, 2003).

(Samanta, 2010) according to the author, Stock market volatility can concern over the growth in output via various feasible alternatives like (a) it's connection with market uncertainties and consequently economic activity, (b) correlation among market volatility and structural change, (c) connection of volatility with cost of capital towards commercial division during predicted returns. The researchers (Siripoulos \& Fassas, 2012) found that there is no statistical asymmetric proof for various volatile indexes which includes the VIX, the VXN as well as the Montreal Volatility index.

(Sarwar, 2012) also studied the effectiveness of the Chicago Board options exchange VIX as an investor fear measure with stock market index from a set of emerging countries such as BOVESPA in Brazil, AK\&M composite index in Russia, SENSEX in India, plus Shanghai SE composite index in China. He concludes in his research that there exists an insignificant relationship among changes in the VIX and the stock market index returns in every market, while the confirmation about the Indian stock market has the positive influence between the time duration from 1993 to 1997.

(Thenmozhi \& Chandra, 2013) examines to pile up the difference formed by the lack of empirical verification regarding the volatile index defines the stock market volatility or not, whose effects is to transfer the risk aversion of investors.

\section{Methodology}

The time period covers for the current study were 8 years i.e., 2009-2017 (Monthly data has been used). The source used was from national as well as international institutions, like NSE, NSDL, and World Bank.

\subsection{Model Specification}

In the model, the Indian Stock Market volatility (Indian volatility index) in India is explained from three independent variables of foreign equity (FE), foreign debt (FD) and foreign direct investment (FDI). The mathematical equation functions are mention as follows:

$$
\text { Indian vix } \mathrm{t}_{\mathrm{t}}=f\left(\mathrm{FE}_{\mathrm{t}}, \mathrm{FD}_{\mathrm{t}}, \mathrm{FDI}_{\mathrm{t}}\right)
$$

To carry out the estimation tests, we convert the equation in logarithm form. The equation incorporated variables like Indian volatility index (Indian_vix), foreign equity (FE), foreign debt (FD) and foreign direct investment (FDI). 
Table 1. Data description

\begin{tabular}{llll}
\hline Variables & Representing Variables & Data Generation & Sources \\
\hline Stock market volatility & Indian Volatility index & Index Data Monthly & National stock Exchange of India \\
\hline Foreign Equity & FE & Monthly & NSDL \\
\hline Foreign Debt & FD & Monthly & NSDL \\
\hline Foreign direct investment & FDI & Monthly & World Bank \\
\hline
\end{tabular}

Stock market volatility data generated from national stock exchange of India website, Foreign Equity and Foreign Debt data generated from national securities depository Limited of India website, Foreign direct investment data is generated from the World Bank website.

$$
\text { LIndianvix }_{t}=a_{0}+a_{1} L F E_{t}+a_{2} L F D_{t}+a_{3} L F D I_{t}+e_{t}
$$

Where LIndianvix $x_{\mathrm{t}}$ is a logarithm form of Indian stock market volatility, LFE is logarithm form of foreign equity, LFD is logarithm form of foreign debt, LFDI is logarithm form of foreign direct investment, $a_{0} \ldots \ldots \ldots \ldots . a_{4}$ is the explanatory power of the variable, $e_{t}$ is the error term.

\subsection{Estimation Technique}

The ARDL Bounds testing approach was proposed by Pesaran and Shin (1999) and Pesaran. (2001) and it is used to establish the presence of a long-run relationship between Indian volatility index, foreign equity, foreign debt and foreign direct investment in India. The purpose of using the ARDL model is lying in the ability to handle relationships even when we have the combination of $\mathrm{I}(0)$ or I(1).ARDL tests the significance of lagged values of variables in the form of error correction of the ARDL model by using the F-statistic value by Okodua and Ewetan (2013). The problem incorporated with the non-standard nature of the asymptotic distribution of measured F-statistic regardless of $\mathrm{I}(0)$ or $\mathrm{I}(1)$ order of integration, persaran (1996) shows the categorize fitted critical values for distinctive numbers of regressors $(\mathrm{k})$ to over this difficulty.

Null hypothesis states if the computed F-statistics drop below the lower bound value, $\mathrm{I}(0)$, then co-integration does not exist, so there is no long-run relationship and if F-statistics is upper than the upper bound value, I(1), then co-integration exist among the variable as well as long-run relationship. In the same context, the error correction ARDL model to be estimated is as follows (Duasa, 2006; Osabohien, 2018).

Error correction model can be anticipated in following manner (Duasa, 2006; Osabohien, 2018):

$$
\begin{gathered}
\Delta \text { LIndianvix }_{t}=\propto_{0}+\sum_{n=1}^{p} \emptyset_{\mathrm{n}} \Delta \text { LIndianvix }_{\mathrm{n}-\mathrm{j}}+\sum_{n=0}^{p} \gamma_{\mathrm{n}} \Delta \mathrm{LFDI}_{\mathrm{n}-\mathrm{j}}+\sum_{n=0}^{p} \theta_{\mathrm{n}} \Delta \mathrm{LFE}_{\mathrm{n}-\mathrm{j}}+\sum_{n=0}^{p} \varphi_{\mathrm{n}} \Delta \mathrm{LFD}_{\mathrm{n}-\mathrm{j}} \\
+\delta_{1} \text { LIndianvix }_{\mathrm{t}-1}+\delta_{2} \mathrm{LFDI}_{\mathrm{t}-1}+\delta_{3} \mathrm{LFE}_{\mathrm{t}-1}+\delta_{4} \mathrm{LFD}_{\mathrm{t}-1}+\mu_{\mathrm{t}}
\end{gathered}
$$

Where $\Delta=$ first difference operator

$\mathrm{P}=$ optimal lag,

F-statistic value will represent the long-run relationship and no long-run relationship and the null hypothesis $\left(\mathrm{H}_{0}\right)$ and alternative hypothesis $\left(\mathrm{H}_{1}\right)$ tested through f-statistic value. $\left(\mathrm{H}_{0}\right)$ tested for no long-run relationship and $\left(\mathrm{H}_{1}\right)$ is for long-run relationship.

$H_{0}: \delta_{1}=\delta_{2}=\delta_{3}=\delta_{4}=0$

$H_{1:} \quad \delta_{1} \neq \delta_{2} \neq \delta_{3} \neq \delta_{4} \neq 0$

The long-run model estimated as follows:-

$$
\begin{aligned}
\text { LIndianvix }_{t} & =\propto_{1}+\sum_{n=1}^{p} \emptyset_{1 \mathrm{n}} \Delta \text { LIndianvix }_{\mathrm{n}-\mathrm{j}}+\sum_{0=0}^{p} \gamma_{1 \mathrm{n}} \Delta \mathrm{LFDI}_{\mathrm{n}-\mathrm{j}} \\
& +\sum_{n=0}^{p} \theta_{1 \mathrm{n}} \Delta \mathrm{LFE}_{\mathrm{n}-\mathrm{j}}+\sum_{n=0}^{p} \varphi_{1 \mathrm{n}} \Delta \mathrm{LFD}_{\mathrm{n}-\mathrm{j}}+\mu_{\mathrm{t}}
\end{aligned}
$$


The short-run model is resultant from the error-correction shown as below:-

$$
\begin{aligned}
\text { LIndianvix }_{t}=\propto_{2}+\sum_{n=1}^{p} & \emptyset_{2 \mathrm{n}} \Delta \text { LIndianvix }_{\mathrm{n}-\mathrm{j}}+\sum_{n=0}^{p} \gamma_{2 \mathrm{n}} \Delta \mathrm{LFDI}_{\mathrm{n}-\mathrm{j}} \\
& +\sum_{n=0}^{p} \theta_{2 \mathrm{n}} \Delta \mathrm{LFE}_{\mathrm{n}-\mathrm{j}}+\sum_{n=0}^{p} \varphi_{2 \mathrm{n}} \Delta \mathrm{LFD}_{\mathrm{n}-\mathrm{j}}+\sigma \mathrm{ECM}_{\mathrm{t}-1}+\mu_{\mathrm{t}}
\end{aligned}
$$

Where,

$\mathrm{ECM}_{\mathrm{t}-1}=$ error-correction term:-

$$
\begin{aligned}
\mathrm{ECM}_{\mathrm{t}}= & \text { LIndianvix }_{t}-\left(\propto_{1}+\sum_{n=1}^{p} \emptyset_{1 \mathrm{n}} \text { LIndianvix }_{\mathrm{n}-\mathrm{j}}+\sum_{n=0}^{p} \gamma_{1 \mathrm{n}} \mathrm{LFDI}_{\mathrm{n}-\mathrm{j}}\right. \\
& \left.+\sum_{n=0}^{p} \theta_{1 \mathrm{n}} \mathrm{LFE}_{\mathrm{n}-\mathrm{j}}+\sum_{n=0}^{p} \varphi_{1 \mathrm{n}} \mathrm{LFD}_{\mathrm{n}-\mathrm{j}}\right)
\end{aligned}
$$

The primary objective is to estimate and investigate the long-run and short association of stock market volatility on foreign direct investment (FDI) as well as economic development. The time-series data period is from 2009 to 2017. In this study, the variables are stock market volatility (Indian-Vix), foreign investment (foreign equity (FE) and foreign debt (FD)), foreign direct investment (FDI).

\section{Results and Discussion}

\subsection{Unit Root Test}

Unit root test was applied with the help of Augmented Dickey-Fuller. It was conducted to confirm that none of the variables are I(2) order and this is required to conduct the bound test. The variables should fulfill the conditions of $\mathrm{I}(0)$ and I(1) order, otherwise, results of bound test will be invalid. Tables showing the ADF test and its results. In the case of Indian-vix, FE, FD the critical value is less than the test statistics so the variable is considered to be stationary in I (0) order. Now the other hand, FDI critical value is more than the test statistics at a level and greater at the first difference, so variable is considered to be stationary in I (1) order. All the above conditions indicate the combination of both I (0) and I (1) variables which justified the function of ARDL regression model.

Through results (Table.1) of ADF test, we obtain similar findings for Indian-vix, FE, and FD that they are stationary at a level whereas FDI is the only variable that becomes stationary at first difference.

Table 2. Augmented Dickey-Fuller (ADF)

Unit root tests results

\begin{tabular}{lrllll}
\hline Variables & T-Statistics Critical Value & Remarks T-Statistics & Critical Value Remarks & OOI \\
\hline Indian Vix & -4.066 & -2.862 & Stationary & & I $(0)$ \\
\hline FDI & -1.566 & -2.862 & Non-Stationary -46.744 & -2.862 & Stationary \\
\hline FE & -6.544 & -2.862 & Stationary & $\mathrm{I}(1)$ \\
\hline FD & $\mathbf{- 5 . 3 9 8}$ & $\mathbf{- 2 . 8 6 2}$ & Stationary & $\mathrm{I}(0)$ \\
\hline
\end{tabular}

Table 3. ARDL bound test

\begin{tabular}{lcccl}
\hline Test Statistic & Value & Significance Level (\%) & \multicolumn{2}{c}{ Critical value Bounds } \\
\hline F-Statistic & & $\mathrm{I}(0)$ & $\mathrm{I}(1)$ \\
\hline & 4.77 & $10 \%$ & 2.72 & 3.77 \\
\hline & $5 \%$ & 3.23 & 4.35 \\
\hline & $2.5 \%$ & 3.69 & 4.89 \\
\hline
\end{tabular}


To determine short \& long-run relationship between the foreign direct investment, foreign equity, foreign debt and the stock market volatility the (ARDL) method is applied. The ARDL method was introduced and developed by Pesaran \& Shin (1998) and was refined later by Pesaran et al. (2001).ARDL model is extensively utilized as it provides an edge in comparison to old statistical methods for assessment of cointegration and short/long-run relationships. Adjusting the data is not necessary for ARDL and long-run relationships can be calculated.

ARDL is to test the level relationship for variables that are either order of integration of $\mathrm{I}(0)$ or $\mathrm{I}(1)$ as well as for a mix of $I(0)$ and $I(1)$ variables (Duasa 2007, Adom et al. 2012). However, ARDL method will not work with non-stationary variables $\mathrm{I}(2)$ order of integration.

To determine short \& long-run relationship between the variables we use ARDL model, this model without dripping long-run information combines the short-run impact of the given variables with a long-run equilibrium by using error correction terms. Furthermore, unlike traditional cointegration tests, it's possible to determine different lags for each variable in the model (Pesaran et al. 2001) which makes it more flexible. Lastly, ARDL method gives powerful and steady results for the small sample size whereas cointegration methods are delicate to the sample size (Pesaran \& Shin 1998, Pesaran et al. 2001, Adom et al. 2012) which is good for our setting as we have small sample sizes.

Table 4. ARDL long-run form

\begin{tabular}{lccc}
\hline Dependent Variable (LIndian_vix) & Co-efficient & \multicolumn{1}{l}{ S.E. } & \multicolumn{1}{l}{ T-Stats } \\
\hline LFDI & -0.16133 & 0.32489 & -0.49656 \\
\hline LFE & -0.08496 & 0.05694 & -1.49209 \\
\hline LFD & $\mathbf{- 0 . 0 3 3 1 8}$ & $\mathbf{0 . 0 4 3 1 1}$ & $\mathbf{- 0 . 7 6 9 7 1}$ \\
\hline
\end{tabular}

Based on the above results, we have employed ARDL model and results are displayed in table 2. Null hypothesis is no levels of long-run relationship between the variables; we have tested and computed the F-statistics (4.77) which is higher than the upper bound critical value at $10 \%, 5 \%$ and providing the evidence of co-integration among the variables at 5\% level of significance. Hence based on results, we reject the null hypothesis and accept that there is a long-run relationship between the variables. So, based on results, we say a co-integration relationship between the Indian_vix, foreign direct investment, foreign equity, and foreign debt exist.

After Results, our all variables come statistically significant and fulfill theoretical expectation in terms of their sign. The coefficient of variables indicates that a $1 \%$ increase in the LFDI will lead to a decrease of about 0.162 percentages in the Indian volatility index.

After examining the coefficient of foreign equity and foreign debt, it shows that a $1 \%$ increase in the variable will decrease 0.084 and 0.033 in the Indian stock market volatility respectively.

Table 5. ARDL error correction model

\begin{tabular}{lccc}
\hline Dependent Variable (LIndian_vix) & Co-efficient & S.E. & T-Stats \\
\hline D(LFDI) & 2.73 & 3.24 & 0.8436 \\
\hline D(LFE) & -1.81 & 5.63 & -0.3219 \\
\hline D(LFD) & $\mathbf{- 1 . 1 9}$ & $\mathbf{7 . 0 9}$ & $\mathbf{- 1 . 6 7 4 3}$ \\
ECM & $\mathbf{- 0 . 9 6 7 1}$ & $\mathbf{0 . 2 2 5 5}$ & $\mathbf{- 4 . 2 8 8 7}$ \\
\hline
\end{tabular}

The short-run dynamics model is shown in table 4, here we are focusing on error correction model. The rules suggested that the ECM must be negative and value of ECM should lie between zero to one. The specified model results show that the ECM value is $(-0.9671)$. This confirms that nearly $96.71 \%$ of the errors generated in each period and automatically corrected in the specified period. The coefficient of the (ECM); Coint Equation (1) is-0.9671, hence It is also statistically significant at the $1 \%$ level. Murthy \& Okunade (2016), it is the requirement for the well-specified ARDL model is the existence of stability. CUSUM test (Graph $1 \& 2$ ) is plotted at 5\% level of significance and CUSUM statistic lies not outside critical bounds of 5\% level of significance. Therefore, we can say 
that the regression model is stable. We have also applied another diagnostic test (Table 5-Breusch-Godfrey Serial Correlation LM Test) for confirming no serial correlation. It was found that there is no serial correlation in the specified model and it is the requirement of the ARDL approach.

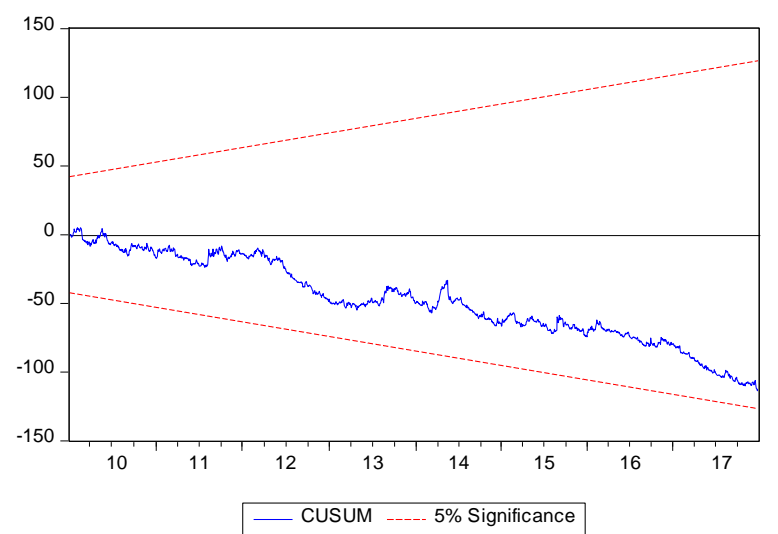

Figure 1. CUSUM test

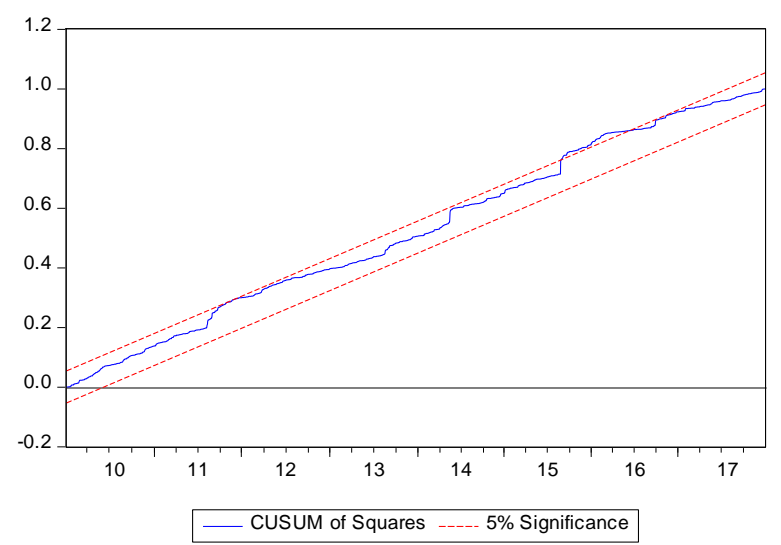

Figure 2. CUSUM square test

Table 6. Test for serial correlation

\section{Breusch-Godfrey Serial Correlation LM Test}

\begin{tabular}{llll}
\hline F-Statistic & 0.002028 & Prob. F(1,2180) & 0.9641 \\
\hline Obs* R-squared & 0.002034 & Prob. Chi-square(1) & 0.9640 \\
\hline
\end{tabular}

\section{Conclusion}

This study investigates the long-run and short-run relationship between Indian vix, foreign direct investment (FDI), foreign equity and foreign debt in India. To get the results ARDL bounds test approach has been adopted. The results indicate the F- statistic value is greater than the upper bound, hence cointegration exists among the dependent \& independent variables. The long-run coefficients indicate a decrease in the stock market volatility exchange. The ECM term is highly significant as the value is in negative sign and p-value also confirms the significance of the ECM term. The CUSUM and CUSUM square test is indicating the model is stable. The Serial correlation is not present in the model, which is indicated by the result of Breusch-Godfrey Serial Correlation LM Test. This study reflects foreign investment play a vital role in the reduction of stock market volatility in India. This is a shred of evidence that foreign investment plays role in stabilizing the stock market volatility. The Indian government had done tremendous efforts to increase foreign investment in the form of a foreign portfolio and foreign direct 
investment. This all happened due to the attention paid by government towards foreign investment. From the result of the study, it recommends that there should be a better-designed plan of foreign investment and setting the target for it will stable the volatility. Further, the government can focus on the hybrid foreign investment which can make the stock market volatility more stable.

\section{References}

Adebiyi, M. A. (2005). Capital market performance and the Nigerian economic growth. Issues in Money, Finance and Economic Management. Lagos: University of Lagos.

Adu, O., Edosomwan, O., Babjide, A. A., \& Olokoyo, F. (2018). Industrial development and unemployment in Nigeria: An ARDL bounds testing approach. International Journal of Social Economics, 46(1), 83-96.

Aliyu, S. U. R. (2012). Does inflation have an impact on stock returns and volatility? Evidence from Nigeria and Ghana. Applied Financial Economics, 22(6), 427-435.

Bae, K. H., Chan, K., \& Ng, A. (2004). Investibility and Return Volatility. Journal of Financial Economics, 71(2). 239-263.

Behera, H. K. (2010). An Assessment of Foreign Investment in Indian Capital Market, Retrieved from http://ssrn.com/abstract=2258352

Bencivenga, V. R., Smith, B. D., \& Starr, R. M. (1995). Transactions Costs, Technological Choice, and Endogenous growth. Journal of Economic Theory, 67(1), 153-177.

Bollerslev, T., Engle, R. F., \& Nelson, D. B. (1994). ARCH models. Handbook of Econometrics,4, 2959-3038.

Campbell, J. Y., \& Hentschel, L. (1992). No news is good news: An asymmetric model of changing volatility in stock returns. Journal of financial Economics, 31(3), 281-318.

Choe, H., Kho, B. C., \& Stulz, R. M. (1999). Do Foreign Investor Destabilize Stock Markets? The Korean Experience in 1997. Journal of Financial Economics, 54(2), 227-264.

Errunza, V. (2001). Foreign Portfolio Equity Investment: Financial Liberalisation and Economic Development. Review of International Economics, 9, 703-726.

Fitz, G. (2003). Policy Issues in Market Based and Non-Market Based Measures to Control the Volatility of Portfolio Investment.

Gupta, M. P., \& Gordon, M. J. P. (2003). Portfolio Flows into India: Do Domestic Fundamentals Matter? (No. 3-20). WP/03/02, International Monetary Fund.

Han Kim, E., \& Singal, V. (2000). Stock Market Openings: Experience of Emerging Economics. The Journal of Business, 73(1), 25-66.

Huang, B. N., \& Yang, C. W. (2000). The Impact of Financial Liberalization on Stock Price Volatility in Emerging Market. Journal of Comparative Economics, 28(2), 321-339.

Ikoku, A. E. (2010). Is the stock market a leading indicator of economic activity in Nigeria?. CBN Journal of Applied Statistics, 1(1), 17-38.

Karolyi, G. A. (2001). Why stock return volatility really matters Institutional investor journals series. Prepared for inaugural issue of strategic investor relations.

Law, S. H., \& Ngah, W. A. S. W. (2008). Does Stock Market Liberalization Cause Higher Volatility in the Bursa Malaysia?. International Journal of Business and Society, 9(1), 19-36.

Lensink, R., \& Morrissey, O. (2006). Foreign Direct Investment: Flows, Volatility and the impact on growth. Review of International Economics, 14(3), 478-493.

Levine, R. (1991). Stock Markets, Growth, and Tax Policy. The Journal of Finance, 46(4), 1445-1465.

Levine, R., \& Zervos, S. (1998). Stock Markets, Banks, and Economic Growth. American Economic Review, 88(3), 537-558.

Miles, W. (2002). Financial Deregulation and Volatility in Emerging Equity Markets. Journal of Economic Development, 27(2), 113-126.

Mitchell, W. C., \& Burns, A. F. (1938). Statistical Indicators of Cyclical Revivals, NBER Bulletin 69, NY. Reprinted in Business Cycle Indicators (G.H. Moore, ed. 1961). Princeton: Princeton U. Press. 
Murthy, V. N., \& Okunade, A. A. (2016). Determinants of US health expenditure: Evidence from autoregressive distributed lag (ARDL) approach to cointegration. Economic Modelling, 59, 67-73.

Nurudeen, A. (2009). Does stock market development raise economic growth? Evidence from Nigeria. The review of Finance and Banking, 1(1), 15-26.

Officer, R. R. (1973). The variability of the market factor of the New York Stock Exchange. The Journal of Business, 46(3), 434-453.

Osinubi, T. S. (2002). Does stock market promote economic growth in Nigeria. The ICFAI Journal of Applied Finance, IJAF, 10(3), 17-35.

Pavabutr, P., \& Yan, H. (2007). The impact of Foreign Portfolio Flows on Emerging Market Volatility: Evidence from Thailand. Australian Journal of Management, 32(2), 345-368.

Pugel, T. A. (2015). Why Everybody Trades: Comparative Advantage. In International Economics (pp. 31-46). New York: McGraw-Hill.

Samanta, G. P. (2010). Stock Market Returns, Volatility and Future Output Growth-Some Obsevations Relating to Indian Economy. Assistant Advisor. NSE.

Sarwar, G. (2012). Is Vix an Investor Fear Gauge in BRIC Equity Markets?. Journal of Multinational Financial Management, 22(3), 55-65.

Schwart, W. O. (1989). Margin Requirement and Stock Volatility. Journal of financial Services Research, 153.

Sehgal, S., \& Tripathi, N. (2009). Investment Strategies of FIIs in the Indian Equity Market. Vision: the Journal of Business Perspective, 13(1).

Siliverstovs, B., \& Duong, M. H. (2006). On the role of stock market for real economic activity: Evidence for Europe. DIW Discussion Papers No. 599.

Siriopoulos, C., \& Fassas, A. (2012). An Investor Sentiment Barometer-Greek Implied Volatility Index (GRIV). Global Finance Journal, 23(2), 77-93.

Thenmozhi, M., \& Chandra, A. (2013). India Volatility Index (India Vix) and Risk Management in the Indian Stock Market. National Stocks Exchange of India (pp. 1-50).

Wei-Chong, C., See-Nie, L., \& Ung, S. N. (2011). Macroeconomics uncertainty and performance of GARCH models in forecasting Japan stock market volatility. International Journal of Business and Social Science, 2(1).

Zafar, N., Urooj, S. F., \& Durrani, T. K. (2008). Interest rate volatility and stock return and volatility. European Journal of Economics, Finance and Administrative Sciences, 14, 135-140.

\section{Website}

https://visualize.data.gov.in/?inst=8f9755dd-14ea-478b-b7abb243a1aa9bdd\&vid=28461\#

https://www.ibef.org/economy/foreign-direct-investment.aspx 